\title{
The Link Between Domestic Political Institutions and Commitments to Tariff Reduction Agreements
}

\author{
Jo, Jung In
}

(LeeUniversity)

\section{$\langle$ CONTENTS〉}

I. Introduction

II. Domestic Constraints of External Trade Policy: Argument

III. Literature Review

IV. Variations of Domestic Political Institutions and the Determination to Enter Preferential Trade Agreements

1. Bueno de Mesquita's Institutional Theory and International Trade Policy
2. Veto players and Trade Policy

3. Electoral System and International Trade Policy

4. Structure of the Government and International Trade Policy

V. Research Design and Hypotheses

VI. Empirical Estimations and Results

1. Estimation Results

VII. Conclusion

- Keyword: tariff reduction agreements, democracy, disaggregated domestic institution types

\section{【ABSTRACT】}

Lately countries have concluded many free trade agreements. However, the puzzle scholars face is why so many countries have rushed to enter a free trade agreement. In this study, I ask how and whether domestic institutions of a country make a difference in committing to tariff reduction agreements. I argue that the rush to PTAs since the 1980s is linked to the domestic constraints. I claim that the propensity of signing a trade agreement increases as the survival of political leaders becomes more dependent on having a large size of winning coalition. Decision-makers have greater political motivations to enter international trade agreements as the level of democracy increases as well. This study tests key propositions drawing on a comprehensive database of international trade agreements from 1950 to 1992 with 150 countries. I find that leaders have greater political incentives to conclude international trade agreements as the size of their 
winning coalition grows. The results also suggest that the level of democracy is associated with a leader's political motivation to conclude international trade agreements. I also find that electoral rule and the number of veto players have an impact on interstate commercial cooperation. By highlighting this dynamic, I demonstrate that domestic institutional constraints deserve more attention in international political economy.

\section{I . Introduction}

Since the early 1980s, many countries have joined Preferential Trading Arrangements(PTAs). Almost every country in the world is a member of a preferential trade arrangement. Sixty percent of world trade occurs within preferential trading blocs. However, the puzzle scholars face is why so many countries have rushed to enter a free trade agreement. Although a recent expansion of preferential trade agreements has stimulated many debates, we lack an understanding as to what motivates states to make a commitment to international trade agreements. This study seeks to improve our understanding of why countries rushed to join trade agreements by examining the impact of domestic institutional constraints.

Scholars have argued that states choose their trade policies because of external factors (Mansfield 1998) and domestic factors such as preferences of political leaders(Rogowski 1989), and preferences of pressure groups(Grossman and Helpman 1993), and political institutions(Milner 1999). More recently, scholars have claimed that interplay between domestic institutions and preferences should be incorporated within the literature regarding the recent change of external trade policy across countries(Milner 1999). However, the literature does not provide a well-developed model as to why political leaders may change their trade policy as domestic political institutions change. Accordingly, the purpose of this study is to provide a more convincing theoretical framework and empirical support incorporating institutional constraints in order to explain why more countries pursue interstate commercial cooperation by entering PTAs. 


\section{Domestic Constraints of External Trade Policy: Argument}

In this study, I argue that the rush to PTAs is linked to the domestic constraints. The model I develop demonstrates that the propensity of signing a trade agreement increases as the survival of political leaders becomes more dependent on having a large size of winning coalition. I also argue that decision-makers have greater political motivations to enter international trade agreements as the level of democracy increases. Other than regime type, there are other disaggregated factors that need to be assessed. Under different circumstances, how can we account for the effects of different domestic institutions in explaining the rush to free trade? There are few systematic studies which analyze disaggregated domestic institution's impact on the change of commercial policy across states with large $\mathrm{N}$ empirical tests. Whether states choose to enter international trade agreements will be influenced by the preferences of political leaders in the first place. Yet, domestic institutions constrain the responsiveness of leaders to the pressure of social demands to change international trade policy. I aim to demonstrate how politicians may implement their particular trade policy in different regimes and how this is linked to a decision to sign tariff reduction agreements. I also aim to demonstrate how the constraints of disaggregated political institutions may be linked to a decision to sign tariff reduction agreements. This paper tests key propositions drawing on a database of international trade agreements from 1950 to 1992 with 150 countries.

\section{Literature Review}

The literature focusing on domestic politics emphasizes the distributional consequences of trade policies for domestic groups. That is, whether a state decides to enter a free trade agreement depends on how much influence different interest groups have in terms of distributional consequences of trade policies (Grossman and Helpman 1993). In general, scholars posit that the losers will oppose the change of trade policy, while winners will support the change of policy(Rogowski 1989). More specifically, scholars provide several perspectives on how trade liberalization will affect the interests of various groups. The Heckscher-Ohlin and Stolper-Samuelson theorems demonstrate that interests and preferences of various groups reflect factoral preference. Free trade will benefit the owners of abundant factors and hurt those holding scarce factors. On the other hand, trade protection will harm abundant-factor owners and benefit scarcefactor owners. Factoral models provide an explanation that "trade-policy preferences of 
different groups will be determined by their countries' relative factor endowments" (Milner 1999).

Another main approach to explaining preferences stresses that preferences of various groups reflect sectoral interests. Proponents of sectoral models(Grossman and Helpman 1994) point out weaknesses such as factoral models' assumption of factor mobility between different sectors. In this model, scholars argue that export industries support free trade and import-competing industries lobby for protection. For instance, the government is willing to sign a PTA when it makes reasonable gains for export groups to the partner country given that there are the costs of import competing industries and voters(Grossman and Helpman 1993).

The empirical evidence on the sectoral-factoral debate is not conclusive. The influence of societal groups cannot be the entire story. Moreover, competition among interest groups to influence governments' policies is usually not structured. Domestic political institutions may structure which groups' preference will be translated to governments' policies(Garrett and Lange 1995). It is also necessary to explore such aspects as the ideological orientations of the political leaders and those of their political support bases.

Another main approach highlights the impacts of political institutions on the external policy of trade. In terms of regime type, there are debates over the monadic impact of regime type on the propensity of trade policy. Scholars have found a positive link between international trade and democracy(Gaubatz 1996, Verdier 1998, Remmer 1998). Gaubatz argues that democracies are more likely to cooperate for freer trade policy due to the system's transparency. Barbieri and Schneider, however, draw a different conclusion about the link between democracy and trade(Barbieri and Schneider 1999). Therefore, debates over the monadic impact of regime type on the propensity of free trade policy are still incomplete(Reinhardt 1996). Some political scientists discuss the dyadic effect of democracy on trade cooperation(Bliss and Russett 1998, Mansfield, Milner and Rosendorff 2002) arguing that "democracies are more likely to commit to rules that reflect their institutional biases"(Simmons 2000). Dixon and Moon suggest that any "two nations with similar regime types are more likely to trade more freely with each other, because similarity decreases political conflict and increases each other' s business exchange" (Reinhardt 1996). On the other hand, Mansfield, and Bronson(1997) argue that democratic dyads are not more likely to cooperate in terms of treaty counts and trade flows. Strong evidence has not yet been presented about the dyadic effect of democracy on trade cooperation. Simmons suggests that the presence of a democratic regime has no independent effect on the propensity to commit to openness (Simmons 2000). Moreover, Dai suggests, "domestic political institutions alone are not sufficient to 
predict a higher level of cooperation among democracies regardless of the preferences of the decision maker" (Dai 2002).

Democracies "vary widely in the extent to which they are open to interest group pressure" and autocratic countries are more sensitive to small groups of their elites (Reindhart 1996). In this context, incorporating the more specific features of domestic institution types such as the electoral system, the number of veto players and so forth may be necessary in order to explore variations of international trade policy. Little empirical research has been conducted to "sort out the complex relationship between the different components of domestic institutions and trade policy"(Milner et al. 2001).

There are international explanations of trade policy as well. Neorealist scholars argue that trade cooperation is more likely among allied states that are close in terms of political and military relationship. Hegemonic stability theory emphasizes that powerful states committed to promoting global trade liberalization are the key to successful economic cooperation. Therefore, the erosion of hegemony tends to cause protectionism. Neo-liberalism argues that international institutions promote cooperation by minimizing collective action problems(Simmons 2000). Mansfield and Reinhardt(2002) argue that, "developments within the GATT/WTO have influenced when member-states have sought the insurance and bargaining power offered by PTAs." In general, this approach is silent as to why and when political leaders are more or less responsive to interstate commercial cooperation initiatives.

\section{Variations of Domestic Political Institutions and the Determination to Enter Preferential Trade Agreements}

There are "little studies, which systematically explore the domestic institutional structures of government and how these domestic political institutions impact the preferences of decision-makers over trade policy"(Ehrlich 2003). In this section, I examine the underexplored linkage between political institutions and the change of trade policies. Understanding the linkage between institutions and trade policy outcomes is significant for grasping the dynamic interplay between the supply side and the demand side of trade policy(Milner 1999).

\section{Buen॰ de Mesquita's Institutional Theory and International Trade Policy}

Political leadership in trade policy-making is an important factor that structures the 
trade policy preferences of countries(Milner 1999). We need well-developed theories that show why and how leaders come to prefer to enter a free trade agreement. In this section, I focus on why political leaders commit to a particular trade policy.

Leader's decisions related to trade policy have domestic distributional and electoral implications. Therefore, deciding whether or not to join trade agreements is a political decision. Leaders are more likely to do what is necessary to satisfy their major constituents' desire in order to retain office. It is assumed that a leaders' political survival depends on successful performance, which is defined by his ability to please the segments of his electoral coalitions. Building from this principle, Bueno de Mesquita provides an interesting perspective for understanding a country's external trade policy. As the winning coalition grows, he argues, "the prospects of political survival hinge on successful policy performance". A winning coalition is defined as "those members of the selectorate whose support is essential to keep the incumbent leadership in office". The selectorate is defined as "all people in a country who have a granted right that gives them a say in choosing the government"(Bueno de Mesquita 2000). Systems with a large winning coalition and a large selectorate are democracies, and those with small coalitions and large-selectorate polities are autocracies for the most part. Systems with a small coalition and a small selectorate tend to be monarchies or military juntas.

Leaders should maintain the loyalty of enough people to keep a winning coalition to stay in office. A small winning coalition implies that a leader needs only the support of a few individuals. Even if the leader's economic policies fail, the essential supporters of an incumbent can be expected to remain loyal, as long as they are happy with their private benefits. Since political leaders in this situation are able to keep their positions by allocating more political resources into private goods, their policy performances are less likely to influence their political survival. That is, leaders do not significantly increase their prospects of remaining in office by spending resources for good public policies. In contrast, leaders in democracies may prefer different strategies. It is difficult for leaders to provide supporters with enough private goods to keep them loyal. It is obvious that coalition members are more likely to defect if the incumbents' policies are seen to have failed." In this situation, policy performances are more likely to impact political leaders' survival. Leaders have the stronger incentive to provide good policy for their citizens. That is, if the size of the winning coalition is larger, more resources will be allocated to produce public goods and therefore better policies such as those which promote free trade will be expected. On the other hand, if the size of a winning

1) There is supportive empirical evidence that poor policy performance increases leaders' risk of being removed, creating an incentive to work hard to prevent policy failure (Bueno de Mesquita 2000). 
coalition is small, poor policy performances are generally expected, because leaders have to use resources to distribute private benefits. Therefore, democratic leaders have a strong incentive to perform well by producing good public policy which autocratic leaders lack. Although this is a simplified explanation of institutions on trade policy choices, the logic of public and private benefits in terms of the strategy of leaders provides a reasonable explanation for the different incentives of leaders regarding a foreign economic policy in different systems. Also, it has been argued that differences within regime types are likely to have more effect on the capacity to initiate trade policy reform than the regime type itself(Milner 1999). Thus, based on the need to investigate the disaggregated impact of political institutions on the decision to enter a free trade agreement, I examine how changes of international trade policy are influenced by the variations of domestic political institutions.

\section{Vete players ${ }^{2)}$ and International Trade Policy}

Veto players in political systems are an important institutional factor in shaping trade policy. Joining a trade agreement is a change of commercial policy. In democratic systems, the process of policy decision involves a variety of institutional and partisan actors. Under these conditions, certain political institutions make it difficult for the government to adopt policy changes. Tsebelis emphasizes "the capacity for policy change" by differentiating political systems on the basis of "veto players". Tsebelis defines a veto player as "the number of actors whose agreement is required for a change of the status quo". He argues that an increase in the number of veto players increases "policy stability" by impeding significant departures from the status quo(Tsebelis 1995). In doing so, Tsebelis claims that countries with many veto players such as coalition governments, bicameral political systems, and presidents with veto power will have a difficulty altering the current policy, resulting in only incremental policy change (Tsebelis 1995). In other words, we expect countries with many veto players to display a lower likelihood of joining a trade agreement. There is a different expectation related to the argument about the number of veto players. Changing status quo policy to comply with PTA conditions requires the approval of other domestic actors with veto power. In this context, a change-oriented leader makes domestic rejection of these policy changes

2) Some scholars use the notion of divided government in order to explore the impact of political institutions in trade policy making. However, "divided government indicates a simple dichotomy. A more sophisticated distinction is the number of separate veto players. A veto player on a given issue dimension may be the person, political party, or faction of a political party, that exercises a veto on that issue by itself"(Cox and McCubbins 2001). 
more costly by tying their commercial policy to an international trade agreement. In some contexts, policy change inflexibility induces a stronger tendency to join a PTA since decision-makers may strategically use a PTA by making government commitments more costly. In this situation, the number of veto players may not negatively influence the propensity of leaders to join international trade agreements.

\section{Electoral System and International Trade Policy}

McGillvray (1997) shows that trade policies may vary according to the types of electoral systems across democracies. Specifically, decision-makers can be more or less insulated from domestic pressures. Some institutions may give interest groups greater access to lobby decision makers. On the other hand, other institutions tend to insulate policy makers from the pressures of interests groups. The electoral system influences the extent of the motivation of decision-makers to respond to pressures from societal groups.

Scholars consider the impact of majoritarian systems and non-majoritarian systems such as an insulated bureaucracy or a legislature elected on the basis of geographic constituencies in determining trade policy. Majoritarian institutions tend to reflect the preferences of the median voter and facilitate the formation of broad-based coalitions. On the other hand, non-majoritarian institutions are likely to stimulate the growth of specific interests. However, there are some mixed effects. In systems with proportional representation, policy makers are more likely to be isolated from societal pressures for protectionism. In large electoral districts and proportional representation(PR) systems, "pressure groups are restrained where campaign resources or the legal control of nominations are centralized in the hands of party leaders, such control is achieved quite effectively in rigid list system"(Rogowski 1987). Thus, there may be a positive relationship between free trade and PR systems. Conversely, Mansfield and Busch claim that larger districts and a PR system result in more protection because of "undermined insulation and autonomy of decision-makers"(Mansfield and Busch 1995) from pressure groups. Therefore, it is less clear that greater insulation of policy makers from societal groups will always produce policies that promote free trade. This proposition regarding the impact of electoral rule needs to be assessed more systematically with alternative explanations, especially those regarding the motivation of leaders to sign a PTA.

\section{Structure of the Government and International Trade Policy}

Scholars have demonstrated that divided government structures in presidential 
systems are associated with a higher level of protectionism(Lohmann and O'Hallonran 1994). This can be an important variable for understanding decisions to join trade agreements, but there is a debate on this issue among scholars. Divided governments are more likely to have a lower level of trade barriers(Mansfield, Milner and Rosendorff 2002), but there are no persuasive theories to explain why divided government is conducive to international cooperation.

Some scholars argue that the congressional delegation of trade policymaking authority to the President allows the President to negotiate reciprocal trade agreements more effectively(Lohmann and O' Halloran 1994). They assert that the delegation of trade policymaking authority to the president "eliminated protectionists' logrolling when passing trade legislation and made more salient the costs of tariffs to consumers". In the same context, Haggard and Kaufman claim that the concentration of trade-policy making capabilities in the hands of the executive branch may motivate strong trade liberalization tendencies across countries(Haggard and Kaufman 1995).

Many comparative studies also suggest that there are qualitative differences between parliamentary and presidential systems in terms of the process and formulation of their policy making. "In a parliamentary system, the executive and the legislature are often linked. Sometimes the legislature has almost no independent power. It makes the executive leaders the sole relevant policymakers. On the other hand, in a presidential system, both the president and the legislature retain independent power. Relevant policy makers can be found in both branches, suggesting that presidentialism should lead to higher tariffs" (Elrich 2003). However, if the legislature delegates trade-policy authority to the president, this may change the situation. It is argued that "delegation of trade policy decision authority to presidents and party leaders is significantly related to trade liberalization. Further, presidents are more insulated from interest group pressure than prime ministers. Therefore, with presidential insulation, we expect that presidential system with strong delegating power should reduce protectionists bias and lead to lower tariff as a result"(Nielson 2003). Therefore, empirical models include the distinction between presidentialism and parliamentarism ${ }^{3)}$ in order to test if presidentialism is more

3) This distinction is a crude measure of executive and legislative relations because there are many institutional variations even among presidential systems and among parliamentary systems. Among presidential systems, presidents have different levels of power over policy making. For example, the president may possess reactive powers, such as the authority to veto or delay legislation. The president may possess a package or line-item veto. Presidents have different levels of proactive power, up to the authority to take unilateral action that does not require legislative approval. These different factors will lead to different effects over international commercial cooperation. "Although the relative merits and consequences of presidential and parliamentary systems have received substantial attention, this distinction between macro institutions is not enough. Explaining political 
prone to international commercial cooperation such as the conclusion of PTAs. I test this hypothesis by investigating how different government systems influence international commercial cooperation.

\section{Research Design and Hypotheses}

Employing the conclusion of a PTA as a dependent variable is a reasonable way to measure the willingness of a country to cooperate with other countries in liberalizing commerce. I take preferential trade agreements, free trade agreements, customs union, common markets, and monetary union as dependent variables.

PTA data is derived from the dataset of Mansfield, Milner and Rosendorff(2002). The dependent variable is the occurrence that states form or join a PTA where we observe 1 if this occurs and 0 otherwise for dyad $i$ during year $t$. That is, it is the binary indicator of whether a dyad forms a PTA in a given year. States are considered to have joined a PTA if they form a new PTA, or if another state joins a PTA in which they are already a member(Mansfield et al. 2002). In order to observe the effect of domestic institutional type in the context of interactive behavior in the international system, I use a dyadic observation as the unit of analysis(Leeds and Davis 1997), as opposed to simply focusing on the determinants of one state's trade policy. I test a hypothesis whether a probability of trade cooperation rises as domestic institutions change in dyads.

In order to measure the size of winning coalition and the selectorate, I draw on the Vanhanen Polyarchy dataset. Vanhanen's(2000) dataset has two indicators: "Participation" and "Competition". Two theoretical dimensions of democracy - public contestation and the right to participate - examined by Dahl seem to correspond to those two indicators in the data set that differentiate more democratic systems from less democratic ones. Legal competition means that individuals and groups are free to organize themselves and to oppose the government. It also indicates the degree to which the freedom of different groups is equal in their competition for power(Vanhanen 2000). The level of participation is also very crucial in democracy as indicated by the relative number of people taking part in politics. The higher the degrees of competition and participation are, the higher the level of democracy is. The participation variable is a useful measure for the selectorate size, and is measured by the percentage of the population that

outcomes often requires greater focus on the details of institutional structure given different institutional arrangements have systematic effects on policy making"(Haggard and McCubbins 2001). 
actually voted in these elections. This variable is prone to large variations even in the same regime.

The measure of winning coalition is the actual size of members of the selectorate whose support is essential to keep the incumbent leadership in office. However, the direct measurement of winning coalition size is more complicated. I use the competition (Vanhanen 2000) and democratization indicator as a proxy for the winning coalition size. Competition measures the electoral success of the smaller parties. It measures the proportion of the votes won by those parties in parliamentary or presidential elections, to indicate the degree of competition in a political system. The competition measurement is useful to distinguish political systems that have had very high participation in elections where in fact there were really no alternatives, as in the former communist states(Gates et al. 2001). This figure is calculated by subtracting the percentage of the votes won by the largest party from 100 percent. If both parliamentary and presidential elections are taken into account, the arithmetic mean of the two percentages is used to represent the smaller parties' share of the vote cast. Because these two variables participation and competition - are assumed to represent different dimensions of democratization, it is plausible to assume that a combination of the two would be a more realistic indicator of democratization than either of them alone. This means that a low value of either of the two variables indicates a low level of democratization.

I draw on Beck, Clark, Groff, Keefer, and Walsh's political institution database for the measurement of electoral system, the number of veto player and the distinction between presidentialism and parliamentarism. The number of veto players is calculated with the following criteria drawn from the Database of Political Institutions: 1 for the executive, 1 if multiple parties are legal and compete in executive elections, 1 for each legislative chamber, and 1 for every veto player whose political orientation is closer to that of the first opposition party than to the party of the executive. For presidential systems, the veto player is the first government party. For parliamentary systems, the veto players are the 3 largest government parties.

It is important to include other confounding variables that may be responsible for a commitment to preferential trade agreements. Studies find that political factors such as alliance positively influence the likelihood of leaders to make a commitment to a PTA. That is, "alliances are likely to promote free trade because countries may be more likely to enter PTAs with their allies when they trust the credibility of their mutual political relationship. When a leader is concerned about the possibility that his ally will cooperate with other opponents, he is less likely to be willing to enter a preferential trade agreement with that ally(Morrow and Siverson 1998). Previous studies also found that 
states are likelier to enter a free trade agreement if they are members of the General Agreement on Tariffs and Trade(GATT) or WTO and if they are not involved in a war(Mansfield 1998). Studies also show the effects of hegemony on the expansion of PTAs(Gilpin 1975, Mansfield 1998). The growth in Preferential Trade Agreements results from the decline in U.S. leadership and power. That is, states join PTAs as hegemony declines. In this context, I control for the effect of hegemony. Hegemony can be calculated as "the percentage of total global trade(the sum of imports and exports) conducted by the state engaging in the most commerce in year $t$ - 1" (Mansfield 1998). The geographic distance between countries is also controlled for because this factor stimulates the formation of PTAs(Mansfield 1998).

Controls for other economic conditions are also included to observe the effects of institutional variables on trade relations. Domestic economic factors can influence a leader's decision to join a preferential trade agreement. For example, states with larger home markets are less likely to be motivated to enter free trade agreements compared to states with smaller home markets)(Milner and Mansfield 1997, Mansfield, Milner and Rosendorff 2002). Thus, the model includes the size of their economy(GDP). I use the lagged per capita real GDP as a control in models. Empirical studies of trade policy also emphasize the level of macroeconomic conditions as the cause for increasing levels of protection. Trade is a field where decision-makers tend to face strong domestic pressures for import protection frequently. When economic conditions are bad, domestic pressures for protection may suddenly occur. In other words, economic conditions influence the level of pressures for protection. "Recessions may lead states to join a PTA comprising countries whose principal industries do not rival each other. Doing so is one way a government can address domestic pressures for protection by restricting imports" (Mansfield 1998). If there are recessions, forming a PTA rather than imposing unilateral trade barriers gives some benefits to member countries of the GATT/WTO. Pomfret(cited from Mansfield 1998) argues, "if a country intends to raise Most Favored Nation tariffs or introduce import quotas, it is both contravening GATT and risking retaliation. A bilaterally negotiated discriminatory trade barrier is a way to sidestep GATT obligations without an open breach." In this sense, increasing levels of unemployment and real exchange rate influence the level of trade policy. That is, political decision-makers should meet the demands for protection from voters based on unemployment level and exchange rate level (Mansfield and Busch 1995). ${ }^{5}$

4) "If the home market is large, the pursuit of scale economies through regional agreements will be less important for firms since they may be close to efficient scale already"(Mansfield 1998).

5) I omit some economic condition variables because of data constraints. 


\section{Empirical Estimations and Results}

The most common techniques for analyzing statistical models with dichotomous dependent variables are logit and probit. However, logit and probit techniques require assumptions of independence among cases that are inappropriate in a time-series cross-section context. Given that the dependent variable is comprised of the decision to join PTAs over time, there must be autocorrelations from year to year per dyad. ${ }^{6)}$ To account for this characteristic of the data, I rely on a generalized estimating equation(GEE) to analyze the data. According to Zorn(2001), the GEE technique is appropriate to use "when the standard assumption that observations in the data are conditionally independent is called into question." GEE analysis uses quasi-maximum likelihood estimation techniques to control the effect of time dependence on observations. ${ }^{\text {?) }}$

I run the analysis with an indicator for each variable, ascribing the weak link principle. Following Oneal and Russett's logic of the "weakest link in the chain," I identify the lower value of winning coalition size in the two countries as the level of winning coalition size. That is, I identify the minimum constraint that the size of winning coalition places on the policy coordination with regards to PTAs within the dyad. I use the same method for other main explanatory variables.

\section{Estimation Results}

Results from the model show that, except for a few variables, the estimation results are consistent with theoretical expectations.

Table 1 presents the results ${ }^{8}$ of the effects of domestic competition level (the proxy of winning coalition) on the determination of leaders to commit to policy change for the formation of international trade agreements. The winning coalition size has a strong positive effect on the commitment to tariff reduction agreements. In other words, the

6) It is notable that many of PTAs are interrelated. "The countries of the European Union and Mexico belong to more than 10 agreements. Brazil, Colombia, Venezuela, Chile and some Central American countries belong to between 5 and 10 agreements. Most other WTO members belong to at least one agreement. The main exceptions to this pattern are Hong Kong, China, Japan, Macau and Mongolia" (Crawford and Laird 2000).

7) To correct the temporal grouping of the dependent variable, cubic splines can be included (Beck and Katz 1995). The splines are designed as a corrective for assuming that observations are timedependent in the time-series cross-sectional framework. However, in this study, I use GEE method instead of using cubic splines approach. It should be noted that using cubic splines as a cure for time dependence effects, does not make a difference in terms of estimation results.

8) I use the command as xtgee ………..... Family (bin), link(logit), robust 
〈Table 1〉 Political Institutions and the Leader's Determination to Join PTAs (Dyadic analysis)

\begin{tabular}{|c|c|c|c|c|}
\hline Dependent Variable: PTAs & Model & Model & Model & Model \\
\hline Independent Variables & 1 & 2 & 3 & 4 \\
\hline Winning Coalition & $\begin{array}{r}.0100425^{* *} \\
(-0.00179)\end{array}$ & & $\begin{array}{r}.006801^{* * *} * \\
(-0.00187)\end{array}$ & $\begin{array}{r}.024606^{* * * *} \\
(-0.00383)\end{array}$ \\
\hline Selectorate & $\begin{array}{r}-0.0025331 \\
(-0.00233) \\
\end{array}$ & & & \\
\hline Democracy & & $\begin{array}{l}.0170693^{* *} \\
(-0.00402)\end{array}$ & & \\
\hline PR & & & $\begin{array}{r}0.0868132 \\
(-0.075971)\end{array}$ & \\
\hline Veto Player & & & & $\begin{array}{c}-.1306064^{*} \\
(-0.062424)\end{array}$ \\
\hline Presidentialism & & & $\begin{array}{r}-.745320^{* * *} \\
(-0.08726)\end{array}$ & \\
\hline GDP & $\begin{array}{r}-4.78 \mathrm{e}-09^{*} \\
-1.30 \mathrm{E}-09\end{array}$ & $\begin{array}{r}-4.65 \mathrm{e}-09^{*} \\
-1.30 \mathrm{E}+00\end{array}$ & $\begin{array}{r}-5.04 \mathrm{e}-09 * \\
-1.35 \mathrm{E}-09\end{array}$ & $\begin{array}{l}-1.95 e^{-09} \\
\left(1.32 e^{-09)}\right.\end{array}$ \\
\hline Trade & $\begin{array}{l}-7.08 \mathrm{E}-08 \\
-6.65 \mathrm{E}-08\end{array}$ & $\begin{array}{l}-7.60 \mathrm{E}-08 \\
-7.03 \mathrm{E}+00\end{array}$ & $\begin{array}{l}-8.44 \mathrm{E}-08 \\
-7.52 \mathrm{E}-08\end{array}$ & $\begin{array}{r}-4.24 e^{-08} \\
\left(2.46 e^{-08}\right)\end{array}$ \\
\hline GATT & $\begin{array}{l}.5703853^{* *} \\
(-0.083011)\end{array}$ & $\begin{array}{r}.560489^{* *} \\
(-0.082915)\end{array}$ & $\begin{array}{r}.461215^{* * * *} \\
(-0.084917)\end{array}$ & $\begin{array}{r}1916965 \\
(-0.139715)\end{array}$ \\
\hline Alliance & $\begin{array}{l}.5437023^{* *} \\
(-0.084138)\end{array}$ & $\begin{array}{r}.544461^{* *} \\
(-0.084974)\end{array}$ & $\begin{array}{r}.5998672 * * * \\
(-0.086107)\end{array}$ & $\begin{array}{r}0.0179184 \\
(-0.159520)\end{array}$ \\
\hline Distance & $\begin{array}{l}-.747404^{* *} \\
(-0.040361)\end{array}$ & $\begin{array}{c}-.726224^{* *} \\
(-0.038911)\end{array}$ & $\begin{array}{c}-.712233^{* * *} \\
(-0.0442127) \\
\end{array}$ & $\begin{array}{r}-.768601^{* * *} \\
(-0.062951) \\
\end{array}$ \\
\hline Colonial history & $\begin{array}{c}1.103073 * * \\
(-0.253312)\end{array}$ & $\begin{array}{r}1.121388^{* *} \\
(-0.246291)\end{array}$ & $\begin{array}{r}.9722216^{* * * *} \\
(-0.24175)\end{array}$ & $\begin{array}{r}1.121388 \\
(-0.2462911) \\
\end{array}$ \\
\hline Hegemony & $\begin{array}{r}-36.7819 * * \\
(-4.00023)\end{array}$ & $\begin{array}{r}-35.6061^{* *} \\
(-3.98042)\end{array}$ & $\begin{array}{r}-38.0425^{* * * *} \\
(-4.055161)\end{array}$ & $\begin{array}{r}-24.4000^{* * *} \\
(-8.054606)\end{array}$ \\
\hline Dispute & $\begin{array}{l}-0.6165609 \\
(-0.447842)\end{array}$ & $\begin{array}{l}-0.5675965 \\
(-0.444860)\end{array}$ & $\begin{array}{l}-0.4183728 \\
(-0.431565)\end{array}$ & $\begin{array}{l}-0.4878087 \\
(-0.720001)\end{array}$ \\
\hline Constant & $\begin{array}{l}5.50663 * * * \\
(-0.693158)\end{array}$ & $\begin{array}{r}5.19899 * * * \\
(-0.676877)\end{array}$ & $\begin{array}{l}5.70743^{* * *} \\
(-0.716907)\end{array}$ & $\begin{array}{r}3.496831 * * * \\
(-1.196047)\end{array}$ \\
\hline$p$ & 0.0000 & 0.0000 & 0.0000 & 0.0000 \\
\hline Wald test chi2 & 861.42 & 869.41 & 873.05 & 277.52 \\
\hline $\mathrm{N}$ & 128199 & 128199 & 128199 & 65921 \\
\hline
\end{tabular}

$* p<.05 ; \quad * * p<.01 ; \quad * * * p<.001$

Huber-White robust standard errors allowed for clustering on each dyad

Robust Standard Errors for Coefficients in Parentheses 
propensity of the determination of leaders to join Preferential Trade Agreements increases as the level of winning coalition size increases. On the other hand, the size of the selectorate shows a negative sign in a dyad on the policy change regarding PTAs. It is not statistically significant. The theoretical implications of selectorate size are less clear according to Bueno de Mesquita(2000). ${ }^{9)}$ These results are consistent and robust across models with different specifications.

Also, democracy continues to have a strongly positive effect on the propensity of commitment to PTAs. That is, the propensity of commitment to sign PTAs increases between democracies.

The number of veto players is negatively associated with the formation of PTAs across models. The likelihood of signing PTAs decreases as the number of veto player increases. In other words, international commercial cooperation on preferential trade agreements is more difficult to achieve as the number of veto player rises in political systems. The number of veto player is an important determinant of Preferential Trade Agreement formation.

The models with weak function application suggest that electoral rules do not influence the likelihood of joint trade agreement cooperation. The estimation results indicate that there is a positive association between PR system and trade policy change for tariff reduction agreements across models. Put another way, the possibility of commitment to Preferential Trade Agreements increases, as the level of the PR system increases. However, as mentioned earlier, electoral rule such as PR neither determines the existence nor success of interstate commercial cooperation. Electoral rule such as PR may allow the higher level of insulation of leaders from the pressures of interest groups and may force to pro-trade tendencies. However, countries such as U.S. and Britain with plurality electoral systems liberalize their trade with international trade agreements more extensively. This result shows that other factors are more prominent in influencing interstate commercial cooperation beyond electoral rule.

The models suggest that presidential political system significantly influences the propensity for joint PTA formation. The estimation results show that the direction of estimates of this variable in the dyad is negative. It means that the possibility of commitment to join Preferential Trade Agreements decreases, as the level of presidential systems increase.

The control variables behave as expected and are unaffected by introducing weak function. The results indicate that the economic size of countries affect the likelihood

9) The effect of selectorate size in this sense is not as clear and more difficult to interpret. 
that leaders sign PTAs. The estimates are negative and statistically significant. It means that as the economic size of country increases, the propensity of leaders to join PTAs decreases. Economic trade level and dispute are not statistically significant. Yet, geographically close states are more likely to enter into PTAs. Geographic proximity is statistically significant across models. Colonial history has a positive effect on the commitment to join PTAs and statistically significant. Hegemony is negative and uniformly statistically significant across models. Alliance has a positive effect on the commitment to join a PTA. The GATT variable shows a positive sign. Countries that are parties to the GATT are more likely to sign a PTA, but this variable is not uniformly statistically significant.

\section{Conclusion}

I attempted to delineate the institutional contexts in which political leaders will be motivated to pursue international trade agreements in the empirical section. Among others, I focus on the effects of institutions such as the size of winning coalition on the likelihood of political leaders concluding a PTA. I also examine how disaggregated institutions may constrain uncertain political competition between leaders, veto players and pressure groups to provide a better understanding of interstate commercial cooperation.

I find that leaders have greater political incentives to conclude trade agreements as the size of winning coalition grows. The probability of signing an agreement increases when the survival of political leaders is dependent on the support of a larger winning coalition. The results also suggest that democratic leaders are more likely to form trade agreements with each other. I also find that government structure and the number of veto players have an impact on interstate commercial cooperation. Based on these empirical results, this study demonstrates that domestic institutional constraints provide an important motivation for leaders to pursue PTAs. That is, domestic constraints can clearly influence policy action at the international level. This study suggests that not only does the domestic regime type influence the likelihood of leaders to conclude PTAs, but also that further disaggregated domestic institutions affect this possibility. In doing so, it highlights the fact that institutional analysis makes a significant contribution towards our understanding of international political economy, especially in explaining how and which political institutions are most conducive to a leader's decision to commit to international trade agreements. 


\section{REFERENCES}

Barbieri Katherine and Gerald Schneider. 1999. "Globalization and Peace: Assessing New Directions in the Study of Trade and Conflict." Journal of Peace Research 36(4): 387-404.

Beck, Nathaniel and Jonathan Katz. 1995. "What to do (and not to do) with Time Series Cross-Section Data." American Political Science Review 89.

Beck, Thorsten, George Clark, Alberto Groff, Philip Keefer, Patrik Walsh, 2001, New Tools and New Tests in Comparative Political Economy, Policy Research Working Paper, World Bank.

Bliss, Harry and Bruce Russet. 1998. "Democratic Trading Partners: The Liberal Connection, 1962-1989." The Journal of Politics 60(4): 1126-47.

Bueno de Mesquita, Bruce, James Morrow, Randolph Siverson and Alastair Smith. 2000.

"Political Institutions, Political Survival, and Policy success." In Governing for Prosperity, ed. Bruce Bueno de Mesquita and Hilton Root. New Haven: Yale University Press: 59-84.

Bueno de Mesquita Bruce. 2000. Principles of International Politics. Washington DC: CQ Press.

Cox, Gary and Mathew McCubbins. 2001. "The Institutional Determinants of Economic Policy Outcomes." In Presidents, Parliaments and Policy, ed. Stephan Haggard and Mathew McCubbins. New York: Cambridge University Press.

Crawford, Jo-Ann and Sam Laird, 2000. "Regional Trade Agreements and the WTO", Paper presented for a meeting of the North American Economic and Finance Association in Boston, 6-9 January.

Dai, Xinyuan. 2002, "Political Regimes and International Trade: The Democratic Difference Revisited”, American Political Science Review 96(1): 159-65

Dixon, William and Bruce Moon, 1993.” Political Similarity and American Foreign Trade Patterns,” Political Research Quarterly, 46.

Ehrlich, Sean. 2003, "Access to Protection Domestic Institutions and Trade Policy in Democracies," Paper prepared for 2003 Midwest Political Science Association Meeting.

Garrett, Geoffrey and Peter Lange. 1995. "Internationalization, Institutions, and Political Change." International Organization, 49: 627. 
Gaubatz, Kurt Taylor. 1996. "Democratic States and Commitment in International Relations". International Organization 50(1): 109-39.

Grossman, Gene and Elhanan Helpman. 1993. The Politics of Free Trade Agreements. Working Paper 4597. Cambridge, Mass.: National Bureau of Economic Research.

Haggard, Stephan and Mathew D. McCubbins. 2001. "Introduction: Political Institutions and the Determinants of Public Policy." In Presidents, Parliaments and Policy, ed. Stephan Haggard and Mathew McCubbins. New York: Cambridge University Press.

Kono, Daniel et al. 1999. "Regional Regimes", Unpublished Manuscript.

Leeds, Brett Ashley and David Davis. 1999. "Beneath The Surface: Regime Type and International Interaction, 1953-78." Journal of Peace Research 36:5-21.

Lohmann, Susanne and O’Halloran Sharyn, 1994. "Divided government and U.S. trade policy: theory and evidence", International Organization 48(4): 595-632.

Mansfield, Edward and Marc Busch, 1995. "The Political Economy of non-tariff barriers: a cross-national analysis", International Organization 49(4): 723-49.

Mansfield, Edward. 1998. "The proliferation of Preferential Trading Arrangements." Journal of Conflict Resolution 42(5): 523-43.

Mansfield Edward and Helen Milner. 1999. "The New Wave of Regionalism”, International Organization 53(3): 589-627.

Mansfield, Edward and Eric Reinhardt, 2002. "Multilateral Determinants of Regionalism: The Effects of GATT/WTO on the Formation of Preferential Trading Arrangements", International Organization.

Mansfield, Edward, Milner Helen, Peter Rosendorff, 2002. "Why Democracies Cooperate More: Electoral Control and International Trade Agreement", International Organization, 56(3): 477-513.

McGillivray, Fiona. 1997. "Party Discipline as a Determinant of the Endogenous Formation of Tariffs.” American Journal of Political Science. 41(2).

Milner, Helen. 1999. "The political economy of international trade." Annual Review of Political Science. 2:91-114.

Milner, Helen and Keiko Kubota. 2001. "Why The Rush to Free Trade: Democracy and Trade Policy in the Developing Countries", Annual Meeting of the American Political Science Association, San Francisco, Aug 30-Sept 2.

Nielson, Daniel. 2003. "Supplying Trade Reform: Political Institutions and Liberalization in Middle-Income Presidential Democracies", American Journal of Political Science, 47(3): 470-491. 
Reinhardt, Eric. 1996. "Posturing Parliaments: Ratification, Uncertainty and International Bargaining", PhD Dissertation, New York: Columbia University.

Remmer, Karen. 1998. “Does Democracy Promote Interstate Cooperation?' International Studies Quarterly 42(1): 25-52.

Rogowski, Ronald. 1989. Commerce and Coalitions. Princeton, NJ: Princeton University Press.

Rosendorff, Peter and Helen Milner, 2001. "The Optimal design of International Trade Institutions: Uncertainty and Escape”, International Organization 55(4): 829-857.

Simmons, Beth. 2000. "International law and state behavior: commitment and compliance in international monetary affairs." American Political Science Review 94:819-35.

Tsebelis, George. 1995. "Decision Making in Political Systems: Veto Players in Presidentialism, Parliamentarism, Multicameralism and Multipartyism”, British Journal of Political Science 25:289-325.

Vanhanen, Tatu. 2000. A New Dataset for Measuring Democracy, 1810-1998. Journal of Peace Research, 37(2): 251-265.

Verdier, Daniel. 1998. “Democratic convergence and free trade?", International Studies Quarterly. 42:1-24.

Zorn, Cristopher. 2001. "Generalized Estimating Equation Models for Correlated Data: A Review With Applications," American Journal of Political Science. 45(2): 470-490. 